\title{
Challenges Facing Internationalization of SMEs in Emerging Economies: A Study on OECD Model
}

\author{
Shouvik SANYAL ${ }^{*}$, Mohammed Wamique HISAM ${ }^{* *}$, Ali Mohsin Salim BAAWAIN ${ }^{* * *}$ \\ Received: November 16, 2019 Revised: December 11, 2019 Accepted: December 18, 2019
}

\begin{abstract}
This research analyses the challenges facing SMEs in Oman in their quest for internationalization. The study is based on the OECD Model of Internationalization put forward in the report titled "How to Foster the Internationalization of SMEs through the Pacific Alliance Integration Process" which focuses on four factors namely finance, business environment, firm capabilities and market access, which are appropriate for an emerging economy like Oman. This study used a descriptive and quantitative research design in attempting to analyze the challenges being faced by Omani SMEs in their endeavors to internationalize. The research investigates causal relationship between variables using positivist and deductive approach. Data collected from 102 respondents was analysed by Structural Equation Modeling(SEM) using AMOS. It was found that finance availability was the most significant predictor of internationalization challenges followed by market access and business environment, while firm capabilities had no impact. Thus SMEs need easier access to credit and have to develop their international business networks and their marketing capabilities in order to grow internationally. Keeping in mind the contribution made by SMEs the government has to intervene by opening up easy lines of credit to SME exporters and allowing them relaxations in customs and other duties.
\end{abstract}

Keywords: Internationalization, SMEs, Oman, OECD Model, Business Environment, Firm Capabilities.

JEL Classification Codes: F60, O14, O19, M13, N65

\section{Introduction}

One of the key challenges facing SMEs as they seek growth and expansion is internationalization. Internationalization is the expansion of economic activities of a firm over a country's national borders. After a firm has established itself in the local market, companies seek to find ways to enter and become competitive in international markets to reap the benefits that accompany

*First Author and Corresponding Author. Assistant Professor, Department of Marketing and Entrepreneurship, College of Commerce and Business Administration, Dhofar University, Oman [Postal Address: Salalah, PO Box. 2509, Zip Code 211, Sultanate of Oman] Tel: + 96823237433

Email: shouviksanyal2000@gmail.com

**Assistant Professor, Department of Management, College of Commerce and Business Administration, Dhofar University, Sultanate of Oman. Email: mhisam@du.edu.om.

${ }^{* * *}$ Lecturer, Department of Management, College of Commerce and Business Administration, Dhofar University, Sultanate of Oman. Email: abaawain@du.edu.om

๑) Copyright: Korean Distribution Science Association (KODISA)

This is an Open Access article distributed under the terms of the Creative Commons Attribution Non Commercial License (https://creativecommons.org/icenses/by-nc/4.0/) which permits unrestricted noncommercial use, distribution, and reproduction in any medium, provided the original work is properly cited. internationalization (Brei, d'Avila, Camargo, \& Engels, 2011). In the process of going global, a firm will start adapting its activity to the international environment by implementing diversified organizational and strategic changes, for example the creation of an export division or the hiring of internationally experienced executives (Calof $\&$ Beamish, 1995). The process and forces behind internationalization present particular challenges and opportunities for SMEs because of a variety of size related influences. Since internationalization leads to an increasing interdependence between national economies (such as with respect to markets, supply chains, sources of capital and production systems), companies have to try and exploit the potential that such interdependence offers, as well as trying to better deal with the related competitive pressure on businesses and jobs, if the SME sector is to fulfil its potential role in national and international economic development.

Internationalization of SMEs is no longer optional as they seek to compete and establish themselves in foreign markets. Internationalization is vital for SMEs to sustain in a competitive world and could contribute to sustaining 
employment opportunities for local youth. Internationalization and increased SME performance are interconnected: international activities help to promote growth, improve competitiveness and improve the longterm sustainability of companies. This internationalization can take many ways: exporting, alliances and joint ventures and foreign direct investment.

From the strategic viewpoint, internationalization is of the crucial importance for the SMEs. One hand expansion into new geographic markets presents a unique opportunity for growth and value creation, but at the same time the implementation of such a strategy involves many unique and tough challenges in addition to the common ones associated with the domestic growth of SMEs. The first phase to entering the international markets traditionally starts with exporting, and it serves as a platform for future international involvement (Kogut \& Chang, 1996). This entry strategy is particularly suitable to SME internationalization because the SMEs frequently lack the resources, for greenfield investment (Dalli, 1995; Zahra, Neubaum, \& Huse, 1997). The bornglobal approach presents a different perspective by outlining the importance of latent and cognitive antecedents (e.g. global mindset and orientation) in the SME internationalization. Earlier, Leonidou, Katiskeas, and Samiee (2002) confirmed the growing importance of the managerial characteristics in the firm's internationalization process.

In the GCC countries, SMEs face a unique set of challenges while seeking to enter foreign markets. This is in part due to the fact that the ecosystem for SMEs is still underdeveloped in these countries and the number of SMEs and their contribution to nations' GDP is relatively small (20\% in the case of Oman in 2018). Lack of foreign market knowledge and scarce managerial talent also contribute to the challenge of internationalization. This study has been conducted in the Sultanate of Oman which is a GCC member country with a medium sized economy. Sultanate of Oman was chosen for this study because of a few reasons. According to the Standard Chartered Index, Oman is the fastest growing economy in the GCC with a GDP of $\$ 79.29$ billion in 2018 . The country is diversifying its economy in the wake of the fall in oil prices, and SMEs are being given priority by the Government given its potential in job creation and exports. The Vision 2040 document envisages an important role for SMEs in the country's endeavor to diversify its economy in order to shield itself from the adverse effects of fluctuations in oil prices. 32441 registered SMEs existed in Oman in 2018 (National Centre for Statistics and Information data).

The SME sector has been facing rough weather since the downturn in oil prices began a few years ago, inspite of governmental interventions and support. Demand for SME products and services has seen a significant downturn. In such a scenario, exploring foreign markets to pursue growth has become an imperative. According to Sui and Baum (2014) internationalization is a viable strategy for SMEs that wish to grow their business in the midst of local and national economic slowdown.

Research into the challenges facing SMEs pursuing internationalization in Oman is scarce. This study aims to plug this gap by attempting to identify the problems and challenges facing entrepreneurs in Oman who wish to take their firms into international markets. This study is based on the factors mentioned in the OECD model of internationalization, namely finance, business environment, firm capabilities and market access, which are appropriate for an emerging economy like Oman. The objective of this research is to find out in what ways these factors act as challenges to the process of internationalization of Omani SMEs.

\section{Literature Review}

SMEs internationalization is a topic that has been well researched in the fields of management, marketing, international business, public policy, entrepreneurship, economics, etc. Wright, Westhead, and Ucbasaran (2001) hypothesized that the topic of internationalization of SMEs have been mainly studied from seven angles: timing and duration of internationalization, sustainability and intensity of internationalization process, mode of internationalization, the domestic environmental context and its influence on internationalization, the importance of leveraging of external resources to internationalize, unit of analysis differences, and effect of internationalization on SME performance. Many researchers have attempted to explain these issues using different approaches and methods. Stage models; Network perspective; Born-global or International New Venture (INV); Resource-based view (RBV) are some of the different views on internationalization of SMEs that have been put forward.

According to Johanson and Vahlne (1977) companies undertake internationalization in stages by leveraging the resources and knowledge they accumulated in the domestic market. The (Uppsala and Innovation-related) model which is gradual behavior-based views internationalization as a learning process that includes knowledge development and gradually increasing foreign market commitments. According to this theory business firms seeking to internationalize encountered entry barriers as a result of 'psychic distance', which refers to socio- economic and political differences between the firm's home market and the target market. These factors include economic and political differences, language barriers, cultural orientations etc. that make it difficult to understand business 
environments on foreign countries (Ruzzier, Robert, \& Hisrich, 2006). According to Child and Hsieh (2014), information and knowledge are key elements in the process of internationalization of SMEs in developing economies.

According to the Knowledge and learning theory SMEs with proactive learning practices achieve internationalization in a more efficient way. Once the process of internationalization is underway, there are predetermined stages that shape the operations of the firm in the host nation. Managers learn about foreign markets opportunities through the stage approach and develop the knowledge and skills necessary to operate abroad. According to Child and Hsieh (2014), information and knowledge are key elements in facilitating international expansion of SMEs and these help in reducing risk and uncertainty and thereby increasing creativity and speed in decision making. Musteen, Francis, and Dutta (2010) found that nurturing knowledge sharing practices through collaborative networks represent an important facilitator in the internationalization of SMEs. According to Costa, Suares, and de Sousa (2015), knowledge sharing, obtaining information about foreign markets though collaborative networks help in achieving rapid international expansion and growth.

The network model developed by Johanson and Mattson (1988) and Bell and McNaughton (2000) describes internationalization as the culmination of a network position in foreign markets. This model applies at two levels: firstly, of the firm in terms of the commitment of resources to a particular market, and secondly at the level of the company through interactions, networking and partnerships. Johanson and Mattson (1988) argued that a company's internationalization is the result of a network wherein companies are enmeshed in a network of connected relationships, and this enable them to obtain much needed resources for foreign expansion. Firms within this network usually establish business relationships with foreign partners facilitate the transfer of resources, especially knowledge and opportunities.

Resource-based view (Penrose, 1959) also provides explanation for why some SMEs are more successful than others in internationalization. According to Penrose, those SMEs which are more dynamic in deploying resources and leveraging capabilities are more successful in international markets. The RBV has two main principles; (1) all firms do not have access to similar resources, and (2) there are costs to be incurred in transferring these resources among firms. Also, just possessing of firm-specific resources does not guarantee competitive advantage. The RBV therefore claims that internal factors that are organizational in nature are responsible for creating competitive advantage and superior performance through internationalization. RBV explains the importance of internal drivers such as tangible and intangible resources for SME internationalization.

The OECD model of internationalization was put forward in a research report by OECD (2015) titled "How to Foster the Internationalization of SMEs through the Pacific Alliance Integration Process". This report was based on studies carried out in South and Central American countries, all of which are emerging economies. This study claims that lack of finance, challenging business environment, firm's internal capabilities and access to markets are the primary challenges face by SMEs that seek to enter foreign markets. The present study considers these variables in analyzing the challenges faced by SMEs in Oman in their attempts to go global.

\section{Issues Facing Internationalization of SMEs in Oman and GCC}

Access to finance is an issue for SMEs all over the world but the problems are compounded in emerging markets. The informal organization structure of most SMEs in Oman lead to problems that are common amongst non - western countries. Banks in the Gulf are generally reluctant to lend to SMEs. According to a study by conducted by Dun and Bradstreet, in 2016 alone banks in Oman rejected as many as $50-70 \%$ of loan applications from SMEs due to the higher risks associated with the small scale sector and due to failure of applicants to provide collaterals and meet other loan conditions. As many as 55\% of SMEs were unable to get the credit they needed to expand, modernize and export. Banks are wary of start-ups ups in particular: Companies that have been in existence for less than two to three years barely received any loans.

Lending to SMEs in Oman and the Gulf region in regional is complicated by several factors. Issues relating to enforcement, recovery and collateral are of key importance: Company assets are often not valuable enough to be used as collateral for larger loans (Carbo-Valverde, RodriguezFernandez, \& Udell, 2009). Banks in the region ask for $150 \%$ of the loan value as collateral, which is quite high in comparison to other countries. Interest rates on loans given are often 10 percentage points and more above Central Bank rates. The banks compensate for possible defaults in this manner, but it becomes difficult for small firms to repay as it requires high returns on capital invested and slows down growth and internationalization plans. There are no dedicated financial institutions to give loans to export oriented SMEs and no credit guarantee schemes. Most lending is short-term, which further increases the pressure on business owners and undermines the long-term business planning needed for technology-intensive diversification. Many owners rely on loans or "love money" from relatives to finance their businesses, which limits the 
prospects for growth. According to Christina and Neelufer (2014), availability of credit on reasonable terms remains a key concern area for SMEs in Oman.

H1: Finance availability poses significant challenge to internationalization of SMEs in Oman

The business environment is also a big challenge facing SMEs that want to internationalize their operations. According to a study by EU-GCC Chamber Forum, SME diversification and internationalization also suffers from the lack of proper information on markets, latest technology and managerial issues. SMEs in Oman are hampered by the absence of indepth and professionally done market studies and whatever little is available is expensive for micro and small businesses to obtain. Hence there is a prevalence of oral information. As a result, most SMEs in Oman have been started without conducting feasibility studies. Business behaviour in the Gulf also tends to be fairly individualistic, and cooperation among SMEs on purchasing, supply chains and marketing is fairly limited in scope. The cooperative structures that exist in other emerging and developed markets whether privately provided or government-assisted, and are of assistance to small businesses, hardly exist in Oman.

Human resources is another issue facing SMEs in Oman that wish to internationalize their operations. According to Magd and McCoy (2014), getting experienced management and accounting professionals with international exposure and experience is a complicated task for small companies, as they are often unable to pay the higher salaries offered by big private companies. Al Balushi and Bagum (2017) found that hiring qualified and internationally experienced managers is one of the main challenges facing SMEs in Oman due to the prevailing labour laws and lower salaries offered. They also cited the lack of a formal relationship between the employees and the owner as a challenge to growth and productivity. This is due to the "Kafeel" system prevalent in Gulf countries wherein the business is registered in the name of a national, but the actual day to day operations are left to expatriate managers and workers. The owner gets a monthly payment without actually getting involved in the business. The lack of career plans and job security for SME employees is another obstacle to accessing talented manpower. Very few SMEs in Oman have a well-planned HR policy and hence, loyalty of workers is limited. This results in a high turnover of local employees, which is a source of frustration for management. The limiting labour laws also make access to skilled and professionally qualified employees a big hurdle.

Innovations and acquisition of skills by business owners is very limited among SMEs in Oman. As long as a regular stream of income can be obtained through limited, regular business activities there will be very little incentive for business owners to innovate in products and processes. The "copycat" behavior often observed in big cities, where dozens of very similar businesses and retail outlets are set up next to each other, might lead to efficient markets but acts as a disincentive for innovation. Simple trading activities and standard services tends to be the main focus of the majority of SMEs. These result in low margins which in turn undermine growth and the accumulation of sufficient resources to implement new business models. They also result in fewer well paid jobs requiring specialized skills and knowledge (Zhu \& Hitt, 2006).

SMEs are also facing operations management constraints in many forms which act like a challenge or issue in growth and internationalization strategies. SMEs in Oman do not have enough skills to hire the best suppliers for them and to maintain a long-term relationship with them. It is very important for a company if it wants to grow a business because when customers or products will increase, then more suppliers or increased supplier's capacity will be needed (Fitzsimmons \& Fitzsimmons, 2013).

H2: The business environment poses significant challenge to internationalization of SMEs in Oman

The firm's internal capabilities also play a major role in the internationalization process. Factors such as management expertise and process and sufficiency of nonfinancial resources are pivotal in the pursuit of expansion and growth overseas. The non-financial factors include availability of office and manufacturing space, experienced management, ability to form partnerships and collaborations, availability of contract manufacturers and service providers and a global mindset of the entrepreneurs are key internal capabilities that an SME must possess before going international (Miocevic \& Morgan,2018). The findings of this study suggest that a significant relationship between global mindset and export market orientation exists suggesting that managerial cognition fosters effective export marketing activity. Kuivalainen (2015) in their study on small ICT firms in Finland came to the conclusion that International experience is a significant determinant of internationalization strategy and performance.

H3: Firm capabilities poses significant challenge to internationalization of SMEs in Oman

Gaining access to international markets is yet another daunting challenge facing SMEs in emerging countries including Oman. There is a lack of networking opportunities and access to country specific market information for SME entrepreneurs. Connecting with customers in global markets in the face of intense 
competition is a key factor which deters entrepreneurs in Oman from going global. Exports and cross border business activities are hampered due to lack of knowledge about business practices and consumer behavior of foreign markets and strategies of competitors, and lack of suitable strategies for sales management (Siringoringo, Prihandoko, $\&$ Kowanda, 2009). The knowledge of new tools like social media for the marketing of SME products and services is not possible for owners that lack in knowledge of marketing management. Due to lack of marketing knowledge, these companies cannot gain an attention of target markets because business world has become very competitive and successful marketing efforts are the key to their success "(Carson \& Gilmore, 2000)". In the case of SMEs, R\&D budget, knowledge and skills are missing which also create many problems in developing right growth and expansion strategies for SME (Knight, 2001).

H4: Market Access poses significant challenge to internationalization of SMEs in Oman

\section{Research Methodology}

The research investigates causal relationship between variables using positivist and deductive approach (Neuman, 2011; Saunders, Lewis, \& Thornhill, 2009). The researchers make observations on the basis of the existing literature. They then build the hypotheses based on the existing theories and collect accurate primary data to support these hypotheses. The results of hypotheses testing shall bring us to either confirmation or development of theories in the future. The causal relationship testing in this research is explanatory (Cooper \& Schindler, 2011); it means that the researchers attempt to explain the process of internationalization of SMEs on the basis of some explanatory variables, namely finance availability, business environment conditions, firms' internal capabilities and market access.

This study used a quantitative approach in attempting to analyze the challenges being faced by Omani SMEs in their endeavors to internationalize. The unit of study is the SME operating in Oman. The data was collected between March 2019 to June 2019. The list of SME entrepreneurs was obtained from the Oman Chamber of Commerce and Industry(OCCI). Cluster sampling technique was employed in order to include SMEs from all governorates of Oman. Primary data was collected using a structured questionnaire which was sent electronically to 132 entrepreneurs. The questionnaire had 25 items and was prepared using likert scales ( $1=$ Strongly Disagree, $5=$ Strongly Agree). Out of these, 102 questionnaires were filled and returned. The data was analysed using Structural Equation Modelling (SEM) to identify the key factors that present challenges in the internationalization process and to find the impact of these factors on this process. SEM is a multivariate technique, which combines factor analysis and multiple regression and enables the researchers to test the causal relationship between latent variables at once (Hair, Black, Babin, \& Anderson, 2010). SEM modelling strategy applies the two-steps approach suggested by Anderson and Gerbing (1988); Confirmatory Factor Analysis (CFA); and also hypotheses testing for the structural model between variables. The results and discussions shall be presented in the next sections.

\section{Results and Discussion}

\subsection{Testing of Structural Model}

Descriptive Statistics: Table 1 shows the demographic profile of respondents. All respondents were Omani SME managers and entrepreneurs $(n=102)$. Most of the respondents (73) were males and majority among them are graduates (65). A majority of respondents (42) are young and in the age group of $36-45$ years.

Table 1: Demographic Profile of Respondents

\begin{tabular}{|c|c|c|}
\hline $\begin{array}{c}\text { Demographic Distribution of the respondents } \\
\text { Variables }\end{array}$ & Number & Percent \\
\hline Age (in years) & & \\
\hline $26-35$ & 27 & 27.00 \\
\hline $36-45$ & 42 & 42.00 \\
\hline $46-55$ & 23 & 23.00 \\
\hline 56 and above & 10 & 10.00 \\
\hline Gender & & \\
\hline Male & 73 & 73.00 \\
\hline Female & 29 & 29.00 \\
\hline Education & & \\
\hline Graduate & 65 & 65.00 \\
\hline Masters & 32 & 32.00 \\
\hline Ph.D & 05 & 05.00 \\
\hline & & \\
\hline
\end{tabular}

As the first step of SEM analysis, the researchers construct a measurement model (CFA). CFA is conducted to ensure the research data are valid and reliable. According to Hair et al. (2010), good validity is illustrated by the minimum value $(0.5)$ of standardized factor loading $(\lambda)$ for each indicator and the minimum value $(0.4)$ of Average Variance Extracted (AVE) (Verhoef, Lemon, Parasuraman, Roggeveen, Tsiros, \& Schlesinger, 2009). After all indicators are declared as valid, a reliability test is conducted. Good reliability is represented by Cronbach's Alpha $(\alpha)$ which should be more than 0.7 and Construct Reliability (CR) minimum 0.6 (Hair et al., 2010). The validity can also be 
displayed through AVE values of each variable, which are recorded at more than 0.4 value. After examining the validity, the researchers should also ensure all variables are reliable. As seen in Table 3, the values of Cronbach's Alpha $(\alpha)$ and CR of each variable are above 0.7, which mean that all variables are reliable. Conclusively, the CFA model proves that the research data were obtained from the valid and reliable measurements.

The structural model was evaluated against five criteria: The chi-square $(\chi 2)$ likelihood ratio statistic, the goodnessof-fit index (GFI), the normed fit index (NFI), the comparative fit index (CFI), and the root mean square error of estimation (RMSEA). The chi-square test of the model was not statistically significant $\chi^{2}(33, \mathrm{~N}=125)=40.31, \mathrm{p}$ $=.127$, which indicates that the model fits the data. The model yielded acceptable fit indices for all indices except one. The other fit measures attained the recommended target values. The value of the GFI was .92, which indicates a good fit. The NFI was .90, which is below the target value of .95. The CFI was .95, and the RMSEA was .041.

Table 2: $\quad$ Fit Indices of the Observed Model $(\mathrm{N}=102)$

\begin{tabular}{|c|c|c|c|}
\hline Fit Index & $\begin{array}{c}\text { Observed } \\
\text { Model }\end{array}$ & $\begin{array}{c}\text { Recommended } \\
\text { Level }\end{array}$ & References \\
\hline$\chi^{2}$ & $40.31, \mathrm{p}=.127$ & Non - significant & $\begin{array}{c}\text { Hair et al., } \\
2010\end{array}$ \\
\hline GFI & .92 & $\geq .90$ & $\begin{array}{c}\text { Myers et al., } \\
2013\end{array}$ \\
\hline NFI & .90 & .95 & $\begin{array}{c}\text { Myers et al., } \\
2013\end{array}$ \\
\hline CFI & .95 & .95 & $\begin{array}{c}\text { Hu \& } \\
\text { Bentler }, 1999\end{array}$ \\
\hline RMSEA & .041 & $\leq .05$ & $\begin{array}{c}\text { Schumacker \& } \\
\text { Lomax, 2004 }\end{array}$ \\
\hline
\end{tabular}

Table 3: CFA - Validity and Reliability

\begin{tabular}{|c|c|c|c|c|c|}
\hline Construct and indicator & Standardized factor loading $(\lambda)$ & AVE & Cronbach's $\alpha$ & CR & Remarks \\
\hline \multicolumn{6}{|l|}{ Finance Availability (FA) } \\
\hline FA1 & 0.708 & \multirow{7}{*}{0.560} & \multirow{7}{*}{0.894} & \multirow{7}{*}{0.897} & Valid \& reliable \\
\hline FA2 & 0.522 & & & & Valid \& reliable \\
\hline FA3 & 0.766 & & & & Valid \& reliable \\
\hline FA4 & 0.799 & & & & Valid \& reliable \\
\hline FA5 & 0.783 & & & & Valid \& reliable \\
\hline FA6 & 0.825 & & & & Valid \& reliable \\
\hline A7 & 0.791 & & & & Valid \& reliable \\
\hline \multicolumn{6}{|l|}{ Business Environment (BE) } \\
\hline BE1 & 0.785 & \multirow{6}{*}{0.654} & \multirow{6}{*}{0.917} & \multirow{6}{*}{0.919} & Valid \& reliable \\
\hline BE2 & 0.837 & & & & Valid \& reliable \\
\hline $\mathrm{BE} 3$ & 0.827 & & & & Valid \& reliable \\
\hline BE4 & 0.874 & & & & Valid \& reliable \\
\hline BE5 & 0.707 & & & & Valid \& reliable \\
\hline BE6 & 0.811 & & & & Valid \& reliable \\
\hline \multicolumn{6}{|l|}{ Firm Capabilities (FC) } \\
\hline FC1 & 0.842 & \multirow{6}{*}{0.537} & \multirow{6}{*}{0.873} & \multirow{6}{*}{0.872} & Valid \& reliable \\
\hline $\mathrm{FC} 2$ & 0.835 & & & & Valid \& reliable \\
\hline FC3 & 0.801 & & & & Valid \& reliable \\
\hline FC4 & 0.587 & & & & Valid \& reliable \\
\hline FC5 & 0.717 & & & & Valid \& reliable \\
\hline FC6 & 0.562 & & & & Valid \& reliable \\
\hline \multicolumn{6}{|c|}{ Challenges in Internationalization (CI) } \\
\hline CI1 & 0.735 & \multirow{6}{*}{0.599} & \multirow{6}{*}{0.897} & \multirow{6}{*}{0.899} & Valid \& reliable \\
\hline $\mathrm{CI} 2$ & 0.841 & & & & Valid \& reliable \\
\hline $\mathrm{CI} 3$ & 0.791 & & & & Valid \& reliable \\
\hline CI4 & 0.776 & & & & Valid \& reliable \\
\hline $\mathrm{CI} 5$ & 0.665 & & & & Valid \& reliable \\
\hline CI6 & 0.822 & & & & Valid \& reliable \\
\hline
\end{tabular}

The second step of SEM modelling is to test the hypothesis of the study by constructing the structural model. The results of the structural model are illustrated in Figure 1 .

Table 4 shows the path coefficients for the structural model. Finance Availability $(\beta=.45, p=.023)$ is the most significant predictor of internationalization challenges followed by Market Access $(\beta=.32, p=.018)$. Business
Environment had a mild positive impact $(\beta=.28, \mathrm{p}=.045)$ while Firm Capability has been found not to have an impact on internationalization of SMEs in Oman.

Thus, the third hypothesis which was that firm capabilities pose a significant challenge to internationalization of SMEs in Oman was not supported while the other three hypotheses were supported by the results of the structural model. 


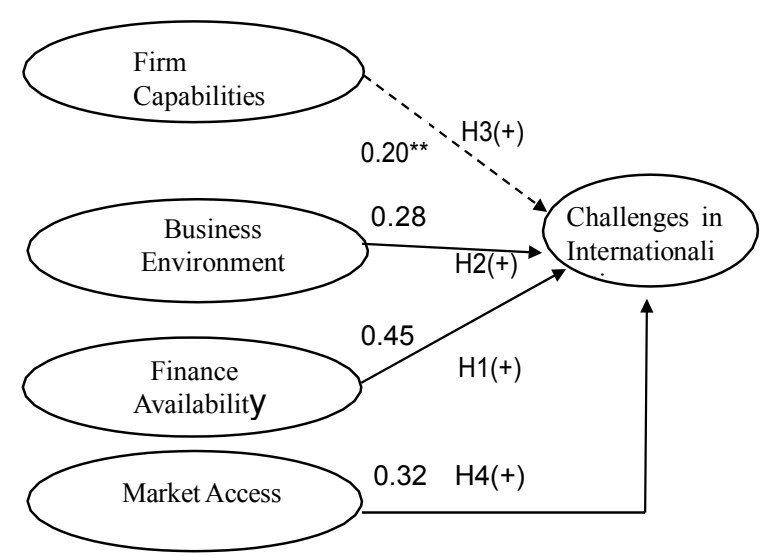

Note: a Standardized path coefficients provided. Non-significant lines are dashed. $* * \mathrm{p} \leq 0.05$.

Figure 1: Structural Equation Modelling Results.

Table 4: Path Coefficients for the Structural Model

\begin{tabular}{|c|c|c|c|c|}
\hline $\begin{array}{c}\text { Relationships } \\
\text { Between } \\
\text { Constructs }\end{array}$ & $\boldsymbol{\beta}$ & $\mathbf{R}^{\mathbf{2}}$ & $\begin{array}{c}\mathbf{p}- \\
\text { value }\end{array}$ & Remarks \\
\hline FA -> CI & .45 & 26.0 & .023 & H1 supported \\
\hline BE -> CI & .28 & 8.0 & .045 & H2 supported \\
\hline FC -> CI & .20 & 0.0 & .213 & $\begin{array}{c}\text { H3 not } \\
\text { supported }\end{array}$ \\
\hline MA-> CI & .32 & 20.0 & .018 & H4 supported \\
\hline
\end{tabular}

\subsection{Discussion}

The primary purpose of the study was to analyze the impact of the four factors identified by the OECD model of internationalization of SMEs on the internationalization of SMEs in an emerging market like Oman. For this purpose, data was collected from 102 respondents who were managers and owners of SMEs. The collected data was analysed using Structural Equation Modelling which is a tool that can analyse the interrelations between all variables simultaneously in a seamless manner. The results show that availability of finance is the most significant challenge faced by the SMEs in the process of internationalization. This is in line with the findings of Zhu and Hitt (2006). Access to foreign markets is the next biggest challenge that SMEs face. This includes logistics and warehousing, export documentation, identifying buyers in foreign markets, international networking etc.

Osei -Bonsu (2014) in their study on internationalization of SMEs in developing countries have come to the same conclusion. Business environment which is volatile and fast changing in the present scenario is also a challenge faces by small firms that wish to globalize. However, the firm's internal capabilities were not considered a hindrance by the respondents in the internationalization process. This may be because the management considered their physical and human resources capable enough before deciding to go international. Thus, by contributing empirical knowledge, this study has provided support to previous studies such as Narayanan (2015) and Serrano and Romero (2014), who tried to identify the barriers to internationalization of SMEs with particular reference to emerging markets. The factors analysed in this study based on the OECD model have been found to be suitable to almost all developing countries.

\section{Conclusion}

This study is one of the very few studies that have been done to analyse the challenges being faced by SMEs in the GCC region in general and Oman in particular during their attempt to access and enter foreign markets. The results of the study are mostly in line with the studies done in other parts of the world including Asia and South America. SMEs require access to lines of credit which conventional banks view as risky. Their access to foreign markets is limited due to the hassles involved in logistics and export documentation which most SMEs don't have the expertise to skillfully manage. It is critical for SMEs to develop their international business networks and their marketing capabilities in order to grow internationally.

One of the most important steps that they can take in this direction is to form network relationships with firms in other countries and look for opportunities for alliances and joint ventures by mutually leveraging their skills. SMEs can also develop a comprehensive website, and exhibitions at key international trade fairs is one of the key ways an SME can develop its international networks and build brand awareness. Lack of managerial talent with exposure to international markets is another significant obstacle that these small firms face. Small business associations can also play a role in encouraging the managers to obtain managerial experience outside the business, particularly in the international arena.

Building much needed managerial capabilities are much needed for successful internationalization and since most SMEs don't have the resources to hire consultants, the government can play a key role by providing advisory services (Osei-Bonsu, 2014). Keeping in mind the contribution made by SMEs to the GDP and exports of Oman, the government has to intervene by opening up easy lines of credit to SME exporters and allowing them relaxations in customs and other duties. Efforts have also to be made to facilitate the logistical aspects of the small enterprises with respect to logistics and documentation. Such interventions have proven to be highly successful in countries like UAE, India and Malaysia and have resulted 
in significant improvement in exports by SMEs and inflow of much needed foreign exchange to these countries.

\section{Limitations and Suggestions for Future Research}

This study suffers from the usual limitations of time and access to respondents. The study has been done in the Sultanate of Oman and can be replicated in other countries or a multi country analysis will offer a wider perspective on these challenges facing internationalization of SMEs. To our knowledge, no such study focusing on the OECD model of internationalization has been attempted in the Middle East. This study is limited to four specific domains and researchers can generalize and broaden the dimensions by looking into other factors and variables which have an adverse impact on the internationalization process of small enterprises in emerging economies. Another limitation of this study is that the data employed in this research were cross - sectional. This implication of using a cross sectional technique is that it may have some common method variance.

Future researches can employ longitudinal analysis that will achieve better measurement reliability. Lastly, researchers can look at SMEs across different sectors to see if the challenges of internationalization vary across industries and verticals. Future studies can consider this study as a template to compare other environmental factors like government policy, bureaucracy, impact of trade barriers and other social perspectives from emerging and developed economies.

\section{References}

Al Balushi, B., \& Bagum, S. (2017). Growth Strategies of SMEs in Oman - Issues and Challenges. International Journal of Small Business and Entrepreneurship Research, 5(2), 21-61.

Anderson, J., \& Gerbing, D. W. (1988). Structural Equation Modeling in Practice: A Review and Recommended Two-Step Approach. Psychological Bulletin, 103(3), 411-423. doi: https://doi.org/10.1037/00332909.103.3.411.

Bell, J., \& McNaughton, R. (2000). Born global firms: A challenge to public policy in support of internationalization. In J. Pelsand \& S. W. Stewart (eds.), Proceeding at the marketing in a global economy conference 2000 (pp. 176-185). Buenos Aires, Argentina: American Marketing Association.

Brei, V. A., d'Avila, L., Camargo, L. F., \& Engels, J. (2011). The influence of adaptation and standardization of the marketing mix on performance: A meta-analysis. $B A R$ Brazilian Administration Review, 8(3), 266-287.

Calof, J. L., \& Beamish, P. W. (1995). Adapting to foreign markets: Explaining internationalization. International Business Review, 4(2), 115-131. doi: http://dx.doi.org/10.1016/0969-5931(95)00001-G.

Carbo-Valverde, S., Rodriguez-Fernandez, F., \& Udell, G. (2009). Bank Market Power and SME Financing Constraints. Review of Finance, 13(2), 309-340.

Carson, D., \& Gilmore, A. (2000). Marketing at the interface: not 'what' but 'how'. Journal of Marketing Theory and Practice, 8(1), 1-8.

Child, J., \& Hsieh, L. H. Y. (2014). Decision mode, information and network attachment in the internationalization of SMEs: A configurational and contingency analysis. Journal of World Business, 49, 598-610.

Christina, B., \& Neelufer, A. (2014). Challenges and Barriers Encountered by SME Owners in Muscat. International Journal of Small Business and Entrepreneurship Research, 2(3), 1-13.

Cooper, D., \& Schindler, P. (2011). Business Research Methods (11th ed.). Boston, MA; McGraw Hill.

Costa, E., Soares, A. L., \& Sousa, J. P. (2015). A New Insight in the SMEs Internationalization Process, Risk and Resilience of Collaborative Networks (pp. 398-410). Cham, Germany: Springer International Publishing AG.

Dalli, D. (1995). The organization of exporting activities: Relationships between internal and external arrangements. Journal of Business Research, 34(2), $107-115$.

Fitzsimmons, J. A., \& Fitzsimmons, M. J. (2013). Service Management: Operations, Strategy, Information Technology ( $8^{\text {th }}$ ed.). Chicago, IL: McGraw Hill Publications.

Hair, J. F., Black, W. C, Babin, B. J., \& Anderson, R. E. (2010). Multivariate Data Analysis ( $7^{\text {th }}$ ed.). Chicago, IL: Pearson Publications.

Hu, L., \& Bentler, P. M. (1999). Cutoff criteria for fit indexes in covariance structure analysis: Conventional criteria versus new alternatives. Structural Equation Modeling, 6(1), 1-55.

Johanson, J., \& Mattsson, L. G. (1988). Internationalization in Industrial Systems-A Network Approach. In N. Hood \& J. Vahlne (Eds), Strategies in Global Competition (pp. 212-234), New York, NY: Scientific Research Publishing.

Johanson, J., \& Vahlne, J.E. (1977). The internationalization process of the firm. Journal of International Business Studies, 8, 23-32.

Knight, G. A. (2001). Entrepreneurship and Strategy in the International SME. Journal of International Management, 7(1), 155-171. 
Kogut, B., \& Chang, S. J. (1996). Platform investment and volatile exchange rate. Review of Economics and Statistics, 78(2), 221-232.

Kuivalainen, O., Sundqvist, S., \& Saarenketo, S. (2015). Internationalization Patterns of Small and Medium Sized Enterprises. International Marketing Review, 29(5), 448-465.

Leonidas, C. L., Constantine, S. K., \& Samiee, S. (2002). Marketing strategy determinants of export performance: a meta-analysis. Journal of Business Research, 55(1), 51-57.

Magd, H., \& McCoy, M. (2014). Entrepreneurship in Oman: Paving the Way for a Sustainable Future. Procedia Economics and Finance, 15, 1632-1640.

Miocevic, D., \& Morgan, R. (2018). Operational capabilities and entrepreneurial opportunities in emerging market firms. International Marketing Review, 35(2), 320-341.

Musteen, M., Francis, J., \& Datta, D. K. (2010). The influence of international networks on internationalization speed and performance: A study of Czech SMEs. Journal of World Business, 45, 197-205.

Myers, M. D. (2013). Qualitative Research in Business \& Management (2nd ed.). London, UK: Sage Publications.

Narayanan, V. (2015). Export Barriers for Small and Medium Sized Enterprises: A Literature Review Based on Leonidou's model. Entrepreneurial Business and Economics, 3(2), 106-123.

Neuman, W. L. (2011). Social Research Methods: Qualitative and Quantitative Approaches ( $7^{\text {th }}$ ed.). Boston, MA: Pearson Publications.

Osei-Bonsu, N. (2014). Understanding the Internationalization Process of Small-to Medium-Sized Manufacturing Enterprises (SMEs): Evidence from Developing Countries. European Journal of Business and Management, 6(2), 167-186.

Penrose, E. (1959). The theory of the growth of the firm. London, UK: Basil Blackwell.

Ruzzier, M., Robert, D., \& Hisrich, B. A. (2006). SME
Internationalization Research: Past, Present and Future. Journal of Small Business and Enterprise Development, 13(4), 476-497.

Saunders, M., Lewis, P., \& Thornhill, A. (2009). Research Methods for Business Students ( $5^{\text {th }}$ ed.). New York, NY: Pearson Publications.

Schumacker, R. E., \& Lomax, R. G. (2004). A beginner's guide to structural equation modeling (2nd ed.). Mahwah, NJ: Lawrence Erlbaum Associates.

Serrano, F. J., \& Romero, I. (2014). About the Interactive Influence of Culture and Regulatory Barriers on Entrepreneurial Activity. Journal of International Business Studies, 45(7), 821-841.

Siringoringo, H., Prihandoko, D. T., \& Kowanda, A. (2009). Problems faced by small and Medium Business in Exporting Products. Delho Business Review, 10(2), 155-173.

Sui S., \& Baum, M. (2014). Internationalization Strategy, Firm Resources and the Survival of SMEs in the Export Market. Journal of International Business Studies, 45, 821-841.

Verhoef, P. C., Lemon, K. N., Parasuraman, A., Roggeveen, A., Tsiros, M., \& Schlesinger, L. A. (2009). Customer Experience Creation: Determinants, Dynamics and Management Strategies. Journal of Retailing, 85(1), 31-41.

Westhead, P., Wright, M., Ucbasaran, D., \& Martin, F. (2001). International Market Selection Strategies of Manufacturing and Services Firms. Entrepreneurship \& Regional Development, 13, 17-46.

Zahra, S. A., Neubaum, D. O., \& Huse, M. (1997). The effect of the environment on export performance among telecommunications new ventures. Entrepreneurship Theory and Practice, 22(1), 25-46.

Zhu, H., \& Hitt, M. A. (2006). The Internationalization of SMEs in Emerging Economies: Institutional Embeddedness and Absorptive Capacity. Journal of Small Business Strategy, 17(2), 154-168. 